\title{
Maciej MAGIERA
}

Uniwersytet im. Adama Mickiewicza, Poznań

\section{O POTRZEBIE BADAŃ KULTURY BEZPIECZEŃSTWA Z PERSPEKTYWY SYTUACJI KRYZYSOWEJ}

Od przełomu XX i XXI w., kiedy koncepcja końca historii Francisa Fukuyamy ostatecznie nie potwierdziła się, doświadczamy zasadniczych zmian w podejściu do bezpieczeństwa. Już na początku pierwszej dekady obecnego stulecia okazało się, że zwycięstwo USA w rywalizacji zimnowojennej nie oznacza bezwarunkowej akceptacji przez resztę świata zachodnich wartości. Nowy konflikt ideologiczny, wyrażony alternatywą dla amerykańskiej wizji New World Order, spowodował ponowne zainteresowanie bezpieczeństwem, ale już w odmiennych warunkach ochrony jednostki. Po pierwsze, procesy globalizacyjne nadały rzeczywistości nowej dynamiki. Po drugie, społeczeństwa chcą czuć się bezpiecznie, ale nie kosztem jakości konsumpcyjnego stylu życia. Po trzecie, coraz bardziej świadome jednostki domagają się rozleglejszej ochrony i te nowe żądania wykraczająjuż poza granice prawa do przeżycia. Wydaje się zatem, że obecnie w cywilizacji zachodniej zawiązuje się potrzeba kompleksowego minimalizowania ryzyk, czyli żądanie poszukiwania potencjalnych zagrożeń praktycznie w każdej dziedzinie życia w celu ich identyfikacji i likwidacji ${ }^{1}$. Spełnienie tego wymogu nie może obejść się bez zasadniczych zmian w podejściu do bezpieczeństwa, szczególnie w kwestiach teoretycznych. Przeciwdziałanie zagrożeniom na tak rozległym obszarze musiało ulec fragmentaryzacji, o czym świadczą m.in. redefinicje terminologiczne i aksjologiczne oraz nowe specjalizacje, jak bezpieczeństwo ekonomiczne, fizyczne, personalne, psychiczne, socjalne, zdrowotne itp.

Niestety ewolucja w postrzeganiu bezpieczeństwa negatywnie oddziałuje na potrzebę kompleksowego minimalizowania ryzyk. Nowe pojęcia, także te o podstawowym znaczeniu, pozostają słabo ugruntowane w teorii, co uniemożliwia rozstrzygnięcie podstawowych niejasności terminologicznych, np. nie ma ostatecznej woli do uznania inności sytuacji kryzysowej (zawsze wielowymiarowej i wielosystemowej) od kryzysu (nagłego zdarzenia, np. zachwiania równowagi jednostki, czyli kryzysu fizjologicznego - zawału czy kryzysu psychicznego - depresji). Ponadto odmienność postrzegania

1 Obecnie potrzeba kompleksowego minimalizowania ryzyk, będąca w zainteresowaniu władzy, zawiera także potrzeby przynależności, uznania i samorealizacji. Odmienna sytuacja przestawiała się wcześniej, kiedy uwagę administracji publicznej przyciaggały głównie potrzeby fizjologiczne i potrzeby bezpieczeństwa jednostki, czyli ustawicznie dążono do ,zaspokojenia podstawowych potrzeb zapewniających bezpieczeństwo i porządek publiczny definiowany jako stan zapewniający ochronę życia, zdrowia, mienia i środowiska przyrodniczo-kulturowego oraz ochrona zasad współżycia społecznego i stosunków regulowanych normami prawnymi i zwyczajami”. Patrz: J. Konieczny, A. Wawrzynowicz, E. Patalas, Ratownictwo w systemie bezpieczeństwa publicznego-wybór źródel, Poznań-Warszawa 2003, s. 7. 
przez badaczy reprezentujących pokrewne dyscypliny naukowe powoduje, że uniwersalne (interdyscyplinarne) definicje stają się albo zbyt skomplikowane, albo zbyt ogólne, przez co mało użyteczne.

Kultura bezpieczeństwa, z perspektywy makro (stosunków międzynarodowych), to zbiór ,przekonań podzielanych przez społeczeństwo oraz elity polityczne odnoszących się do polityki bezpieczeństwa, a więc miejsca danego państwa w systemie międzynarodowym, w węższym sensie do politycznych aspektów użycia siły militarnej. Koncepcja ta zakłada rozpoznanie sposobów konstruowania narodowych interesów bezpieczeństwa, ogniskując swą uwagę na zjawisku oddziaływania specyficznych, uformowanych historycznie wzorców i norm" "2. W kontekście mikro (środowiska pracy) kultura bezpieczeństwa sprowadza się do stanu świadomości większości pracowników o zagrożeniach, nieformalnych i formalnych normach postępowania w sytuacji kryzysowej, indywidualnych wartości, które uwzględniają bezpieczeństwo i ochronę zdrowia. Jedna i druga definicja, mimo że przydatna dla rodzimej specjalności, okazuje się tymczasem mało użyteczna dla innej. W konsekwencji niepewna, ponieważ słabo ugruntowana, teoria w obszarze bezpieczeństwa potęguje trudności w kompleksowym minimalizowaniu ryzyk, o czym świadczą zmiany legislacyjne, mało precyzyjne rozwiązania prawne, ciagła modyfikacja procedur itp.

Wszystko to powoduje, że dociekanie na gruncie teoretycznym wymaga potwierdzenia w praktyce. W społeczeństwie zbudowanym na większych lub mniejszych sprzecznościach warto odnieść się do kwestii łagodzenia konfliktów społecznych ${ }^{3}$, a dokładniej poruszyć problematykę bezpieczeństwa z perspektywy sytuacji kryzysowej $^{4}$, która staje się doskonałym papierkiem lakmusowym ukazującym rzeczywisty stan zarządzania kryzysowego, czyli „,działalności organów administracji publicznej będącej elementem kierowania bezpieczeństwem narodowym, która polega na zapobieganiu sytuacjom kryzysowym, przygotowaniu do przejmowania nad nimi kontroli $\mathrm{w}$ drodze zaplanowanych działań, reagowaniu w przypadku wystapienia sytuacji kryzysowych, usuwaniu ich skutków oraz odtwarzaniu zasobów i infrastruktury krytycznej zmiany" ". Poruszanie się w kontekście sytuacji kryzysowej umożliwi poznanie potrzeby kompleksowego minimalizowania ryzyk, ukaże działalność administracji publicznej z punktu widzenia bezpieczeństwa i przede wszystkim pozwoli zbadać zależności między beneficjantami (jednostką, zbiorowością, społeczeństwem) a szeroko pojętym aparatem państwowym i samorządem (nie tylko terytorialnym, ale także zawodowym czy gospodarczym).

${ }^{2}$ K. Malinowski, Kultura bezpieczeństwa narodowego: koncepcja i możliwości zastosowania, w: Kultura bezpieczeństwa narodowego w Polsce i w Niemczech, red. K. Malinowski, Poznań 2003, s. 16.

${ }_{3}$ Z socjologicznego punktu widzenia potrzeba badań nad konfliktowością społeczeństwa wynika z kultury zaufania, która ,,prowadzi w prostej linii do tego, że w sferze zachowań społecznych ludzie mogą czuć się wolni od jakichkolwiek zagrożeń, a co za tym idzie, są spokojni o swą przyszłość i mają możliwość własnego rozwoju". Patrz: E. Moczuk, Socjologiczne aspekty bezpieczeństwa lokalnego, Rzeszów 2009, s. 13.

4 Sytuacja kryzysowa została użyta w szerszym ujęciu i nie należy jej utożsamiać z kryzysem, ponieważ drugie pojęcie zawiera się w pierwszym (w fazie kryzysu). Patrz: W. Kitler, Istota zarzadzania kryzysowego, w: System reagowania kryzysowego, red. J. Gryz, W. Kitler, Toruń 2007, s. 20.

5 Art. 2, Ustawa o zarzadzaniu kryzysowym, 26 kwietnia 2007, Dz. U. 2007, Nr 89, poz. 590. 


\section{ZNACZENIE KULTURY BEZPIECZEŃSTWA}

Skoro udało się ustalić, że konkretna sytuacja kryzysowa staje się w praktyce studium przypadku kompleksowego minimalizowania ryzyk, to warto zastanowić się w jaki sposób można wpłynąć na jej przebieg. W tym miejscu należałoby odnieść się do kultury bezpieczeństwa, ponieważ sprowadza się ją do sposobu ,postrzegania wyzwań, szans i zagrożeń, sposobu myślenia o bezpieczeństwie oraz sposobu odczuwania jego braku, a także sposobu zapewnienia bezpieczeństwa"6. Jednak nie w rozumieniu mikro (środowiska pracy) czy makro (sfery międzynarodowej), ale „mezoskali, wypełniając swoistą lukę między tymi skrajnymi podejściami badawczymi"”. Wtedy kultura bezpieczeństwa w kontekście sytuacji kryzysowej staje się zbiorem przekonań, podzielanych przez społeczność oraz elity polityczne (władze samorządowe i terenowe), odnoszących się do lokalnej polityki bezpieczeństwa, a więc miejsca danego regionu w systemie zarządzania kryzysowego, w węższym sensie do politycznych aspektów (zakresu działań) zapobiegania, przygotowania, reagowania i odbudowy.

Powyższa modyfikacja (propozycja) ma służyć tylko uchwyceniu roli kultury bezpieczeństwa w zarząazaniu kryzysowym, a dokładniej jej wpływu na zachowania uczestników określonej sytuacji kryzysowej. Większej precyzyjności trudno oczekiwać przy obecnym stanie wiedzy, lukach w teorii i w okresie intensywnych zmian w sposobie postrzegania rzeczywistości przez pryzmat potencjalnych i wszechobecnych zagrożeń. Dodatkowo „łatwiej zdefiniować pojęcie bezpieczeństwa niż kultury bezpieczeństwa, choć $i$ to pierwsze nie poddaje się łatwo próbom generalizacji. $Z$ uwagi na fakt, że do pojęcia bezpieczeństwa odnosi się zarówno czynnik subiektywny, związany z postrzeganiem zagrożeń, jak i obiektywny, który odzwierciedla realne, rzeczywiste zagrożenia, to i kultura bezpieczeństwa musi się w tym zawierać, co zresztą nie wyczerpuje problemu. Byłaby to więc kultura świadomościowa, duchowa (subiektywna), odnosząca się do bezpieczeństwa, jak i kultura organizacyjna różnych podmiotów, także struktur wielostronnych (subiektywno-obiektywna) oraz kultura materialna, związana z obronnością (technika, technologie, infrastruktura) traktowana jako obiektywna" ${ }^{8}$. Zatem kultura bezpieczeństwa, rozumiana w mezoskali oraz oparta na zasobach, organizacji i mentalności, warunkuje działania w sytuacji kryzysowej, wpływa na skuteczność zarządzania kryzysowego ${ }^{9}$ i sprzyja potrzebie kompleksowego minimalizowania ryzyk. Wyodrębnione trzy komponenty pojęcia stały się punktem wyjścia do dalszych rozważań nad sposobem poprawy jakości przeciwdziałania zagrożeniom, które najefektywniej, ponieważ bezpośrednio i w uciążliwych okolicznościach, wpływa na zadowolenie i poczucie bezpieczeństwa jednostki.

${ }^{6}$ M. Cieślarczyk, Tożsamość stużb reagowania kryzysowego w świetle socjologicznego modelu kultury bezpieczeństwa, w: Tożsamość społeczna grup dyspozycyjnych, red. J. Maciejewski, W. Nowosielski, Wrocław 2009, s. 44.

7 M. Cieślarczyk, Kultura bezpieczeństwa i obronności, Siedlce 2011, s. 11.

8 J. Czaja, Kulturowe czynniki bezpieczeństwa, Kraków 2008, s. 222.

9 Celowo nie zastosowano pojęcia zarządzanie sytuacją kryzysową (crisis managment), ponieważ priorytetem w dociekaniu pozostają relacje między administracją publiczną a jednostkami doświadczonymi sytuacją kryzysową. 
W polskiej rzeczywistości kultura bezpieczeństwa pozostaje marginalizowana, ale ten stan rzeczy wydaje się chwilowy. Większe zainteresowanie dotychczas niezauważonym pojęciem zachodzi, dzięki potrzebie kompleksowego minimalizowania ryzyk, która nasila się w naszym społeczeństwie. Po pierwsze, trend dostrzegania ryzyka w każdej dziedzinie życia wynika przede wszystkim z upowszechnienia się przekonania, że właśnie bezpieczeństwo stanowi podstawę prorozwojowej egzystencji jednostki. W warunkach europejskich, i szerzej w cywilizacji zachodniej, wolność od zagrożeń od dawna stała się niezbywalną, respektowaną i gwarantowaną prawodawstwem wartością. Jednak zmiana, jaka zaszła na przełomie wieków, polegała na zaakceptowaniu nowej filozofii, w której humanistyczny indywidualizm został zastapiony humanistycznym uniwersalizmem. Zatem powrócono do przekonania, że „struktury, całości, takie jak państwo, społeczeństwo, naród, są ważniejsze od poszczególnych ludzi, którzy je współtworzą i którzy są ich częściami”" ${ }^{\prime 0}$. Po zamachach z 11 września 2001 r., wobec potrzeby kompleksowego minimalizowania ryzyk doszło do uprzedmiotowienia jednostki. Ograniczono wolności w zamian za obietnicę zapewnienia stabilności w każdej dziedzinie życia. Na znaczeniu zyskał humanitarny wymiar bezpieczeństwa: „doszły takie wartości chronione, jak: jakość i poziom życia, dobrobyt ludności, szanse rozwoju, zachowanie tożsamości kulturowej oraz więzi spajające społeczeństwo"11. Podtrzymywanie strachu, podkreślanie nieprzyjaznego otoczenia, fobia traktowania każdego z nieufnością i podejrzeniem zapewniło zdobycie wystarczającego kapitału politycznego do zwiększenia autorytaryzmu, uciszenia przeciwników inwigilacji czy zrzeczenia się przez obywateli fundamentalnych praw. Dogmatyczne podejście do bezpieczeństwa, czyli chęć uzyskania totalnej ochrony jednostki, doprowadziło do absurdalnych poglądów. W kontekście stosunków międzynarodowych neokonserwatywnej administracji George'a W. Busha udało się nawet przekonać znaczącą część opinii międzynarodowej, że dotychczas oczywista i powszechna rywalizacja ekonomiczna między amerykańskim hegemonem a resztą świata stanowi akt wypowiedzenia wojny. Paradoksalnie proces ten został zainicjowany w państwie opartym na dogmacie: „,każdy kto rezygnuje $\mathrm{z}$ wolności na rzecz bezpieczeństwa nie zasługuje ani na jedno, ani na drugie".

Po drugie, wzrost znaczenia bezpieczeństwa wynika także z ciagłego, choć fluktuacyjnego, postępu technicznego i technologicznego. Nowoczesne rozwiązania ułatwiające jednostkom funkcjonowanie jednocześnie stały się doskonałym, bo łatwo dostępnym źródłem zagrożenia. Internet, symbol globalizacji, umożliwił nam komunikację bez ograniczeń czasowych i przestrzennych, ale upowszechnił także nowe ryzyka. Te można ograniczać tylko na poziomie państwa, które zajmuje specyficzną pozycję w systemie międzynarodowym, posiada aparat przymusu i większe możliwości akumulacji zasobów niż sektor prywatny. Zatem obywatele pozbawieni skutecznych narzędzi w przeciwdziałaniu wszechobecnym zagrożeniom stali się częścią społeczeństwa ryzyka. „W zaawansowanej nowoczesności społeczna produkcja bogactwa idzie w parze ze

10 W. Rechlewicz, Elementy filozofii bezpieczeństwa. Bezpieczeństwo z perspektywy historii filozofii i filozofii polityki, Warszawa 2012, s. 30.

11 S. Kwiatkowski, Zarzadzanie bezpieczeństwem w sytuacjach kryzysowych. Szkice socjotechniczne o madrości przed szkoda, Pułtusk 2011, s. 54. 
społeczną produkcją ryzyka. W związku z tym problemy i konflikty dystrybucji społecznego niedostatku przysłonięte zostały przez problemy i konflikty, które powstają przy produkcji, definiowaniu i podziale ryzyka wytworzonego przez naukę i technikę" " Najogólniej mówiąc takie społeczeństwa uzależniły się od innowacji będącej jednocześnie dobrodziejstwem i źródłem nowych ryzyk. Większa mobilność powoduje wzrost zagrożenia epidemiologicznego, a automatyzacja sprzyja otyłości czy uzależnieniu od substancji chemicznych. Digitalizacja, w kontekście sytuacji kryzysowych, umożliwia stosowanie symulacji komputerowych, np. przy określeniu w czasie rzeczywistym skutków spiętrzenia się wody na wybranym obszarze, a z drugiej strony świat wirtualny stał się idealnym środowiskiem dla nietradycyjnych zagrożeń. Wojna cybernetyczna, czyli nowa kategoria konfliktu o losowych zwycięzcach i nieprzewidywalnym przebiegu, stała się doskonałym narzędziem, aby przy niewielkich nakładach wywołać nieocenione straty, o czym przekonały się władze Estonii ${ }^{13}$.

Po trzecie, doświadczenie z pierwszej dekady XXI w. ukazało, że skuteczność ${ }^{14}$ zarządzania kryzysowego zależy głównie od uzyskanych informacji. W zglobalizowanym otoczeniu kompleksowe minimalizowanie ryzyk nie jest możliwe bez wiedzy o potencjalnych zagrożeniach i ich realnym wystąpieniu, a to wymaga już działań prewencyjnych. Politykę bezpieczeństwa państwa rozszerzono więc o działalność analityczno-informacyjna, która ,wymaga innych metod i środków niż dotychczasowe ściganie i egzekwowanie prawa" ${ }^{\text {" }}$. W skutek tego informację traktuje się jako dobro publiczne, podstawę naszego systemu, a jej przetwarzanie, przekazywanie, zbieranie, kontrolowanie i ochrona stało się zawodem coraz większej części społeczeństwa. Zatem w warunkach XXI w. naturalna potrzeba bezpieczeństwa zaspokojona być może tylko przy odpowiednich zasobach informacyjnych, a te, uzyskane poprzez nowoczesne technologie informacyjne, także przyczyniają się do niekontrolowanego wzrostu świadomości społeczeństwa. Elektroniczne środki przekazu zwiększają dostęp do informacji poprzez likwidację ograniczeń narzucanych przez czas i przestrzeń. Co więcej, internet stał się środkiem komunikowania, które nie podlega (nadal opiera się) naciskom ze strony władz. Jednostki wykorzystują nowe media (środki przekazu, które uaktywniają odbiorcę i znoszą klasyczny podział nadawca-odbiorca) do autonomicznego zaspokajania potrzeby edukowania. W efekcie, nie całe społeczeństwo, ale osoby posługujące się informacją do analizy rzeczywistości, kwestionują kosztowne i nadzorowane przez określone grupy interesów źródła informacji, jak mainstreamowa telewi-

12 U. Beck, Społeczeństwo ryzyka. W drodze do innej nowoczesności, Warszawa 2004, s. 27.

13 Zmasowany atak hakerów w maju 2007 r. zakończył się elektroniczną destabilizacją tego państwa, a dokładniej zablokowaniem serwerów i stron internetowych Zgromadzenia Państwowego, agend rządowych, banków i środków masowego przekazu.

14 Skuteczność, czyli umiejętność dopasowania do ,zmieniających się warunków społecznych, ważnych w procesach dostosowawczych, a więc ustawiczne zbieranie sygnałów z otoczenia i odpowiednia modyfikacja działań”. Patrz: J. Konieczny, Sprawna administracja ochrony bezpieczeństwa i porzadku publicznego, w: Administracja ochrony bezpieczeństwa i porzadku publicznego w Wielkopolsce. Stużby, inspekcje i straże, red. J. Konieczny, Poznań 2010, s. 34.

15 S. Sulowski, O nowym paradygmacie bezpieczeństwa w erze globalizacji, w: Bezpieczeństwo wewnętrzne państwa. Wybrane zagadnienia, red. S. Sulowski, M. Brzeziński, Warszawa 2009, s. 18 . 
zja, radio czy drukowana prasa ${ }^{16}$. Zatem kapitał ludzki kształtuje się samodzielnie, a jednostki coraz bardziej uświadomione i pełne obaw przed potencjalnymi i wszechobecnymi zagrożeniami zaczynają coraz więcej wymagać od administracji publicznej, a nawet potrafią narzucać władzy własne konkretne rozwiązania. Pewne niebezpieczeństwo tego trendu sprowadza się do braku kontroli nad komunikatami rozpowszechnianymi w ogólnoświatowej sieci komputerowej, co często prowadzi do informacyjnego chaosu i wzajemnego niezrozumienia. Odbiorca otrzymuje nieprzydatne treści czy niewłaściwie przetworzone w wyniku niezamierzonego lub świadomego działania (celowego fałszowania), a to negatywnie oddziałuje na poczucie bezpieczeństwa. Przecież „Zwycięstwo [w wojnie psychologicznej, walce informacyjnej] zależy nie tylko od zapewnienia i uzyskania przewagi informacyjnej na temat przeciwnika, ale także od zagwarantowania sprawnego przepływu sprawdzonych, rzetelnych i aktualnych informacji pomiędzy własnymi instytucjami" ${ }^{17}$. Kiedy państwo przegrywa te batalie, to wśród jednostek wzrasta zniecierpliwienie, pretensjonalność oraz subiektywne poczucie zagrożenia.

W czasie mistrzostw Euro 2012 w sposób pionierski, jak na polskie warunki, doświadczono jakości obsługi uczestników turnieju w wyniku zwiększonych nakładów (zasobów), niecodziennej mentalności i przyjaznej, choć generującej koszty, organiza$\mathrm{cji}^{18}$. W efekcie pojawiły się postulaty utrzymania standardów stosowanych w czasie turnieju, a nawet żądania zniesienia zakazu spożywania napojów niskoalkoholowych w miejscach publicznych. Hasła te wydają się opierać na fałszywych przesłankach, ponieważ zawierają błędne przekonanie o tożsamych realiach turniejowych i naszej codzienności. Dzięki odniesieniu się do kultury bezpieczeństwa w kontekście sytuacji kryzysowej udało się na wstępie ustalić, że relacje interpersonalne w zarządzaniu kryzysowym uzależnione są od trzech czynników: zasobów, organizacji oraz mentalności. $Z$ dużym prawdopodobieństwem można założyć, że ten ostatni komponent wyróżniał uczestników tej międzynarodowej imprezy masowej, co dyskwalifikuje sztywne transponowanie rozwiązań.

\section{ROLA MENTALNOŚCI W KULTURZE BEZPIECZEŃSTWA}

Społeczeństwo w Polsce ulega zachodnioeuropejskim wpływom, więc również u nas pojawiają się identyczne trendy, potrzeby i żądania, a to wymusza zmiany w systemie zarządzania kryzysowego. Kompleksowe minimalizowanie ryzyk w polskiej

16 Środki masowego przekazu, z tzw. głównego nurtu, starają się przeciwstawić tendencji schyłkowej i często wspomagają się potencjałem internetu. Proces ten polega na zwiększaniu atrakcyjność przekazu poprzez poruszanie informacji, która wcześniej nabrała rozgłosu w sieci.

17 P. Bączek, Zagrożenia informacyjne a bezpieczeństwo państwa polskiego, Toruń 2006, s. 243.

18 Uznać można, że sukces Euro 2012, przynajmniej w Wielkopolsce, wynikał ze zmiany mentalności, kiedy „działania podejmowane przez osoby odpowiedzialne za zabezpieczenie turnieju nie mogły stać w sprzeczności z duchem imprezy i potrzebami jej uczestników. Zabezpieczenie Mistrzostw Europy w piłce nożnej było raczej dodatkowym serwisem dla kibiców, który nie powinien zakłócać ich radości i przeżywanych emocji, lecz jedynie umożliwić wspólną zabawę w wolnej od poczucia zagrożenia atmosferze". Patrz: Przewodnik Wszyscy jesteśmy gospodarzami. Organizacja masowych imprez sportowych na przykładzie Euro 2012, Warszawa 2012, s. 20. 
praktyce sprowadza się do systematycznego zwiększania zasobów, np. przez modernizację służb ratowniczych i podnoszenie poziomu organizacji, np. przez nowe ustawodawstwo, międzynarodowe szkolenia kadr ${ }^{19}$, czy transfer know-how. Jednak działania te nie dadzą oczekiwanego rezultatu, jeśli dalej marginalizowany będzie problem relacji międzyludzkich. Utrzymanie status quo w tej materii spowoduje, że nie będzie można osiagnąć standardów zachodnich nawet przy nieograniczonych nakładach (zasobach) czy nieustannej poprawie organizacji. Przecież realia sytuacji kryzysowej bezwzględnie weryfikują jednostki (decydentów) z niedostateczną świadomością czy mentalnością, która sprzyja w kryzysie np. nadużyciom przy zaopatrzeniu czy nieefektywnym wykorzystaniu nowoczesnego sprzętu ratowniczego. Z perspektywy kultury bezpieczeństwa, a ta ma kluczowe znaczenie w przeciwdziałaniu sytuacjom kryzysowym, to mentalność (trzeci komponent) wymaga fundamentalnej reformy, o czym świadczy praktyka Euro 2012 w Poznaniu.

Osiagnięcie zachodnich standardów wymaga zreformowania sposobu myślenia polskiego społeczeństwa, które nadal zmaga się z dziedzictwem PRL. W Polsce z punktu widzenia potrzeb i oczekiwań upodobniliśmy się do zachodu, ale od niego odróżnia nas wysoki poziom uzależnienia od państwa. Nadal, przynajmniej w kwestiach socjalnych, propaguje się urzędniczy protekcjonizm zbliżony do poprzedniego systemu, w którym opiekowano się jednostką od kołyski aż po grób. W rezultacie nasuwa się wątpliwość, czy transformacja objęła także naszą mentalność, skoro nadal zrzucamy odpowiedzialność na państwo nawet w takich kwestiach, jak zapewnienie wykształcenia dającego pewność zatrudnienia czy walka z wykluczeniem społecznym (alienacją). Trwanie w systemie państwa opiekuńczego negatywnie wpłynęło także na aktywność jednostek. Z perspektywy społeczeństwa ryzyka w cywilizacji informacyjnej pasywizm, obwinianie systemu, przeciętność, egalitaryzm ograniczają nasze funkcjonowanie. Niedoskonałości wynikające z rozwoju (nowe rodzaje ryzyk) i świadomość nieodwracalnych zmian (swoboda w przepływie informacji) mogą powodować u osoby, która mentalnie nadal tkwi w systemie realnego socjalizmu, dysonans kulturowy, apatię, poczucie bezsilności i brak zainteresowania sprawami publicznymi. W efekcie taka jednostka nie spełnia wymagań społeczeństwa obywatelskiego, staje się biernym przedmiotem podległym aparatowi państwa, a to negatywnie wpływa na skuteczność zarządzania kryzysowego. W przypadku zagrożenia ujawnia się nieetyczna postawa roszczeniowa czy zamiera osobista aktywność obywatelska zgodnie z tezą potwierdzaną w badaniach, kiedy ,respondenci wyrażają opinię o potrzebie umacniania międzyludzkiej solidarności, ale w rzeczywistości deklaracje te nie przekładają się na aktywne działania" ${ }^{20}$.

Od naszej mentalności zależy nie tylko przebieg sytuacji kryzysowej, skuteczność systemu zarządzania kryzysowego czy ogólny poziom bezpieczeństwa. Skorelowane z nią pozostają wszystkie składniki kultury bezpieczeństwa, ponieważ ani bogate zaso-

19 Warto przypomnieć, że metody organizacyjne Euro 2012 zostały wypracowane na podstawie własnych doświadczeń i tych uzyskanych od wcześniejszych organizatorów tej piłkarskiej imprezy masowej.

20 M. Leszczyński, Bezpieczeństwo społeczne Polaków wobec wyzwań XXI wieku, Warszawa 2011 , s. 143 . 
by (wyposażenie służb w nowoczesny sprzęt), ani prawidłowa organizacja (opracowane procedury) samodzielnie nie zapewnią sukcesu podmiotom odpowiedzialnym za bezpieczeństwo. Zdarzenia kryzysowe bezlitośnie ujawniają fatalne skutki nieodpowiedzialnych zachowań czy braku rozsądku np. przy zabudowie obszarów uznanych w planach zagospodarowania przestrzennego za tereny zalewowe lub nadmierne spożywanie alkoholu na imprezach masowych ${ }^{21}$. Często te zaniedbania uniemożliwiają skuteczne działanie antykryzysowe nawet tych służb unowocześnionych materialnie i organizacyjnie. Dodatkowo w okresie niestabilności, np. w czasie klęski żywiołowej, wolne od wpływu otoczenia jednostki, kiedy nie oddziałują na nie normy czy nie egzekwuje się prawa, sprzyjają hobbesowskiej kulturze. ,W okresach stabilnych wpływ ten może być niewidoczny, gdyż repertuar kulturowy jest skorelowany z podstawowymi zasadami istniejącego środowiska międzynarodowego. Inaczej dzieje się w okresach transformacji tego środowiska, kiedy więź między zachowaniem a kulturą staje się wyrazistsza i nacechowana napięciem - istniejąca kultura jest wystawiona na adaptacyjną presję, a aktorzy sięgają po jej symbole dla utrzymania swojej dotychczasowej polityki"22. Zatem zachowanie jednostki, szczególnie w dotkliwym dla niej okresie, zależy właśnie od prezentowanej kultury bezpieczeństwa, jej jakości oraz odporności na presję zmieniającego się otoczenia. Warto podkreślić, że często porządkowi publicznemu szkodzi głównie nieetyczna postawa jednostek, które w imię konsumpcjonizmu godzą się na maksymalizację zysków nawet za cenę pobudzania ekstremistycznych postaw.

Spojrzenie z perspektywy sytuacji kryzysowej odzwierciedla rzeczywista, a nie deklarowaną specyfikę otoczenia, uwidacznia zderzające się interesy grup społecznych, ukazuje stan przygotowania podmiotów odpowiedzialnych za bezpieczeństwo i ujawnia kondycję świadomości uczestników zdarzenia. Warto zatem przyjrzeć się głównym czynnikom determinującym kulturę bezpieczeństwa, która w realiach nowej filozofii społeczeństwa ryzyka cywilizacji informacyjnej szczególnie oddziałuje na potrzebę kompleksowego minimalizowania ryzyk.

\section{DETERMINANTY KULTURY BEZPIECZEŃSTWA W PRZECIWDZIALANIU SYTUACJI KRYZYSOWEJ}

Interpretacja rzeczywistości podlega emocjom, co komplikuje stosowane w praktyce rozwiązania. Społeczeństwo w Polsce nadal dogmatycznie podchodzi do bezpieczeństwa i żąda całkowitej ochrony w każdej dziedzinie życia, a ewentualne kryzysy uznaje za usuwalne natychmiast. Przecież doświadczenia z pierwszej dekady XXI w. ukazały, że w nowych uwarunkowaniach podmioty, nawet te $\mathrm{z}$ bogatych państw, odpowiedzialne za bezpieczeństwo gorzej radzą sobie z ochroną coraz bardziej mobilnego społeczeństwa $^{23}$. Zatem trzeba brać pod uwagę nie tylko naturę ludzka, ale dopasowywać się do

${ }^{21}$ Odniesienie się do dwóch jakże odmiennych przykładów ma uświadomić rozpiętość problemów bezpieczeństwa widzianych z perspektywy mezoskali.

${ }_{22}$ K. Malinowski, Kultura bezpieczeństwa..., op. cit., s. 31-32.

23 Państwo w wyniku globalizacji nie może zagwarantować swoim obywatelom całkowitego bezpieczeństwa, choćby uwolnić ich od zagrożeń terrorystycznych, międzynarodowej przestępczości 
emocjonalnego stanu otoczenia, reagować elastycznie na jego zmianę i być gotowym na nowe możliwości funkcjonowania. Strategie działania, kierunki modernizacji zasobów i organizacji wynikają z kompromisu, który stanowi wypadkową partykularnych interesów i w efekcie nie zaspokaja potrzeb w całości. W tym przypadku kultura bezpieczeństwa, wypracowana na podstawie ocen i doświadczeń z przeszłości, ma kształtować w jednostkach subiektywną hierarchizację wartości. Na podstawie wiedzy, umiejętności i w wyniku systematycznego inspirowania w niej postawy twórczej, osobowości otwartej, samodzielności myślenia i zdolności do samokształcenia się ${ }^{24}$ można wypracować docelowo zdroworozsądkową altruistyczną postawę warunkowaną historycznie ${ }^{25}$.

Po drugie, pożądana kultura bezpieczeństwa nie jest celem samym w sobie, ale ma spełniać określone funkcje, czyli: dostarczać optymalne rozwiązania, uporządkować zadania i określić drogę ich realizacji według potrzeb społecznych, a także zapewnić taką interpretację prawa, aby najefektywniej działać w sytuacji kryzysowej. W rzeczywistości staje się ona modulatorem między teorią a praktyką, a dokładniej sprowadza się do problemu nadinterpretacji przez władzę wykonawczą intencji legislatywy. Prawo, mimo relatywnie homogenicznych realiów sytuacji kryzysowej, musi pozostać na tyle ogólne, by mogło być stosowane w każdych warunkach. Kiedy prawodawca porzuca uniwersalizm, wtedy nie nadąża za zmianami otoczenia, co często objawia się niewydolnością zbyt szczegółowo skonstruowanych procedur albo niemożnością zastosowania pewnych rozwiązań, ponieważ w prawie nie przewidziano takich możliwości. W przypadku Euro 2012 pojawił się interesujący, choć nie podjęty na szerszą skalę, problem podejścia służb mundurowych do osób (kibiców) spożywających napoje alkoholowe poza strefami tej piłkarskiej imprezy masowej.

Po trzecie, każde społeczeństwo zbudowane jest na sprzecznościach, co często prowadzi do niejasnych wyborów jakie partykularne interesy poprzeć. W przypadku imprezy masowej pierwsza trudność pojawia się już przy wyznaczeniu miejsca jej organizacji, gdy cierpi spokój okolicznych mieszkańców ${ }^{26}$. W czasie klęski żywiołowej władze szczególnie poddane są konfliktogennej presji, np. kiedy w trakcie powodzi godzą się zalać tereny mniej zaludnione, aby uratować nadbrzeżną część aglomeracji czy miasta. Jeśli interesy określonych grup zderzają się nieprzerwanie, co wpływa na skuteczność zarządzania kryzysowego, wówczas kultura bezpieczeństwa ma przeciwdziałać radykalizacji i dezintegracyjnym zjawiskom. Jednostki chętniej współpracują, kiedy odczuwają wsparcie administracji publicznej działającej w sposób skoordynowany (zorganizowany) i życzliwy (mentalnie sprzyjający poszkodowanym). Uznać należy, że sukces organizacji Euro 2012 w Poznaniu był skutkiem profesjonalizmu

zorganizowanej, niekontrolowanych migracji transgranicznych itp. Szerzej: E. Nowak, M. Nowak, Zarys teorii bezpieczeństwa narodowego, Warszawa 2011, s. 134-136.

24 M. Cieślarczyk, Kultura bezpieczeństwa..., op. cit., s. 101.

25 „Doświadczenie historyczne wyznaczając poprzez normy spektrum możliwych strategii działania, nadaje podjętym w tych ramach wyborom walor legitymacyjny". Patrz: K. Malinowski, Kultura bezpieczeństwa..., op. cit., s. 35.

26 W czasie przygotowań do Mistrzostw Europy w piłce nożnej w 2012 r. przedstawiciele Urzędu Miasta Poznania, by nie doszło do protestów, pertraktowali z mieszkańcami warunki funkcjonowania Strefy Kibica na Placu Wolności w Poznaniu. 
i elastyczności podmiotów odpowiedzialnych za bezpieczeństwo oraz wynikał z połączenia maksymalnego bezpieczeństwa z przyjazną przestrzenią publiczną (zmianą mentalności). Zabezpieczenie imprezy masowej przebiegało zgodne $\mathrm{z}$ hasłem baw się dobrze - czuj się bezpiecznie opartym na zintegrowanej koncepcji bezpieczeństwa. Przyjęto wtedy filozofię 3 razy T: troska (otwartość i gotowość do wspierania kibiców i gości w ramach swoich kompetencji), tolerancja (informowanie o niestosownych zachowaniach naruszających miejscowe prawa lub powszechne, służenie radą i podpowiedzią), tłumienie (zagrożenie dla życia lub zdrowia ludzi albo niszczenie mienia przy nieskutecznych negocjacjach uprawnia do szybkich i profesjonalnych działań nawet $\mathrm{z}$ użyciem siły $)^{27}$.

W rezultacie determinanty kultury bezpieczeństwa, czyli kreowanie postawy jednostki, modulowanie interpretacyjne oraz neutralizowanie konfliktów społecznych, warunkują przeciwdziałanie sytuacji kryzysowej i tym samym stają się wyznacznikami autonomicznego działania administracji publicznej w kompleksowym minimalizowaniu ryzyk ${ }^{28}$.

$$
* * *
$$

Nowa filozofia bezpieczeństwa, chęć utrzymania dotychczasowego poziomu konsumpcji, społeczeństwo ryzyka, dynamizacja rzeczywistości, podwyższona świadomość, łatwość w dostępie do informacji przeobraziły potrzeby egzystencjalne naszego społeczeństwa. Polityka bezpieczeństwa państwa oparta na gwarancji przetrwania stała się przestarzała i wymaga modyfikacji, by zapewnić obywatelom egzystencję na wysokim poziomie, a przede wszystkim wyjść naprzeciw ich oczekiwaniom. Kierunek przeobrażeń został już określony, o czym świadczy pozytywna reakcja na realia Euro $2012^{29}$. W Wielkopolsce dąży się do utrzymania postawy podmiotów odpowiedzialnych za bezpieczeństwo, kiedy tolerancja i negocjacje stały się najważniejszymi elementami filozofii działania. Dzieje się tak, ponieważ oczekiwania wyrosłe z potrzeby kompleksowego minimalizowania ryzyk, przynajmniej w kontekście imprezy masowej, zdały się spełnione. Jednak utrzymanie zachodnich kanonów wymaga przemian w naszej kulturze bezpieczeństwa, szczególnie w ramach trzeciego jej komponentu. Polskie społeczeństwo zbudowane na sprzecznościach w zglobalizowanej rzeczywistości wymaga permanentnej modyfikacji mentalności. Inaczej konflikty społeczne,

27 Przewodnik Wszyscy..., op. cit., s. 21.

28 W czasie trwania Euro 2012, znaczenie kultury bezpieczeństwa widoczne było, kiedy decydenci służb mundurowych, szczególnie na Stanowisku Dowodzenia w Wielkopolskiej Komendzie Wojewódzkiej Policji w Poznaniu, stawali przed wyborem, czy nadal tolerować, a może już tłumić niepożądane zjawiska, np. wspinanie kibiców na kamienice Starego Rynku, kapiel w miejskich fontannach czy łamanie przepisów drogowych przez niezorganizowane grupy kibiców.

29 Badanie ankietowe przeprowadzone od 12 do 14 czerwca 2012 r. metodą CATI za pomocą wystandaryzowanego kwestionariusza wywiadu na reprezentatywnej kwotowej próbie 400 mieszkańców Poznania z bazy danych Wydziału Komunikacji Urzędu Miasta Poznania wykazały, że $83,5 \%$ badanych pozytywnie zweryfikowało przygotowania organizatorów turnieju w Poznaniu. Patrz: http://www.poznan.pl/mim/wiadmag/news/badanie-atmosfery-podczas-uefa-euro-2012-w-poznaniu,53121.html (17.11.2012). 
jako zjawiska obiektywne, powszechne, często nierozwiązywalne przekształcą się w destruktywne i nie do powstrzymania siły. Natura ludzka ulega hobbesowskiej kulturze, o czym świadczą częste przykłady sytuacji kryzysowych w małej skali. Przeważnie, jeśli nie zawsze, tratowanie, przemoc, walka towarzyszy ograniczonej promocji określonego produktu czy otwarciu wielko-powierzchniowego sklepu z jednodniowymi rabatami. Z dużym prawdopodobieństwem można założyć, że w warunkach jeszcze mniej sprzyjających dojdzie do skrajnych zachowań, kiedy „,człowiek pragnie dóbr materialnych i duchowych bez uwzględnienia praw do tych dóbr ze strony innych ludzi, co w prostej linii prowadzi do wojny" ${ }^{30}$. Temu zjawisku należy przeciwdziałać poprzez systematyczną $\mathrm{i}$ ukierunkowaną modyfikację kultury bezpieczeństwa, by wzmóc w społeczeństwie chęć współpracy, empatię i pozbawić go nadmiernego egoizmu. Przecież rozpoznanie i eliminowanie nowych zagrożeń zależy „od przygotowania infrastruktury technicznej państwa, ale przede wszystkim od inwencji człowieka, kreatywności zespołów rozwiązujących problemy oraz sprawności zarządzania posiadanymi zasobami" ${ }^{31}$.

Docelowo kultura bezpieczeństwa w Polsce ma sprzyjać współpracy, by efektywniej wpływać na przebieg sytuacji kryzysowej i potencjalnych zagrożeń, które coraz bardziej zwracają uwagę społeczeństwa ${ }^{32}$. W przeciwnym razie staniemy się zbiorowością coraz bardziej roszczeniowych jednostek z tendencją do ignorowania skutków w przyszłości, w której ponosić będziemy nieproporcjonalne do zysków koszty przy kompleksowym minimalizowaniu ryzyk. Stoimy przed wyjątkowo trudnym zdaniem, ponieważ sprawne przeciwdziałanie sytuacjom kryzysowym wymaga zreformowania wszystkich komponentów kultury bezpieczeństwa, nie tylko tych łatwo transponowanych (zasobów i organizacji). Zatem w społeczeństwie ryzyka cywilizacji informacyjnej zbudowanym na większych lub mniejszych sprzecznościach kompleksowe minimalizowanie ryzyk możliwe będzie tylko przy wzajemnej chęci do ustępstw, a to sprowadza się do radykalnej ingerencji w naszą mentalność. Tego rewolucyjnego zadania nie uda się zrealizować bez właściwego narzędzia, jakim wydaje się być kultura bezpieczeństwa.

W warunkach XXI w. każdy, kto pragnie pozostać wolny od ryzyk, musi porzucić specyficzną mentalność odziedziczoną po poprzednim systemie. Przyzwolenie na zwiększanie się roli państwa w rzeczywistości poddanej globalizacji przy jednoczesnej krytyce jego efektywności prowadzi do dysonansu kulturowego, apatii i zobojętnienia. W polskiej rzeczywistości przebieg sytuacji kryzysowej warunkuje pasywizm społeczny, przychylność do państwa opiekuńczego, brak odpowiedzialności za własne czyny, co ogranicza efektywność systemu zarządzania kryzysowego i komplikuje działania antykryzysowe. $Z$ tej perspektywy kultura bezpieczeństwa wyznacza pewną konwencję, określa zespół norm, zwyczajów regulujących i interpretujących politykę bezpieczeństwa państwa, umożliwia dobór rozwiązań w zarządzaniu kryzysowym, określa

${ }^{30}$ K. Drabik, Zagadnienia ontologiczne wojny, bezpieczeństwa i pokoju w pogladach wybranych myślicieli, Warszawa 2011, s. 214.

31 P. Bączek, Zagrożenia..., op. cit., s. 249.

32 Temu zainteresowaniu sprzyja także specyfika środków masowego przekazu, dla których najbardziej przydatne są informacje ogólnie pojmowane jako kryzysowe w negatywnym tego słowa znaczeniu, np. brak kultury spożywania alkoholu czy barbaryzacja zachowań w czasie imprez masowych. Patrz szerzej: K. Sienkiewicz-Małyjurek, F. Krynojewski, Zarzqdzanie kryzysowe w administracji publicznej, Warszawa 2010, s. 195-196. 
ich charakter i funkcję w poszczególnych fazach ${ }^{33}$. W pewnym sensie narzuca reguły, ogranicza radykalizm w reformowaniu mentalności, czy szerzej przystosowaniu naszego społeczeństwa do nowych warunków w XXI w., co pozwoli nam na szybszą i mniej kosztowną adaptację do otoczenia. W tym właśnie spostrzeżeniu zawiera się istota tytułowej potrzeby badań kultury bezpieczeństwa.

\title{
STRESZCZENIE
}

Nowa filozofia bezpieczeństwa, chęć utrzymania dotychczasowego poziomu konsumpcji, społeczeństwo ryzyka, dynamizacja rzeczywistości, podwyższona świadomość, łatwość w dostępie do informacji przyczyniły się do zawiązania w polskim społeczeństwie potrzeby kompleksowego minimalizowania ryzyk, czyli żądania poszukiwania potencjalnych zagrożeń praktycznie w każdej dziedzinie życia $\mathrm{w}$ celu ich identyfikacji i likwidacji. Wydaje się, że wsparciem dla administracji publicznej w spełnieniu tych nowych społecznych oczekiwań może być kultura bezpieczeństwa, ponieważ warunkuje ona działania w sytuacji kryzysowej, wpływa na skuteczność zarządzania kryzysowego i przede wszystkim sprzyja usystematyzowaniu wiedzy, co pozostaje ważne przy słabo ugruntowanej, bowiem ciagle modyfikowanej, teorii. Dzięki odniesieniu się do trzech komponentów kultury bezpieczeństwa (zasobów, organizacji i mentalności) dało się zauważyć, że sprawne przeciwdziałanie sytuacjom kryzysowym będzie niemożliwe bez radykalnej ingerencji w naszą mentalność. $Z$ tej perspektywy kultura bezpieczeństwa wyznacza pewną konwencję, określa zespół norm, zwyczajów regulujących i interpretujących politykę bezpieczeństwa państwa, a to ułatwia dobór, pożądanych przez społeczeństwo, rozwiązań w zarządzaniu kryzysowym.

\section{ABOUT THE NEED FOR SECURITY CULTURE STUDIES FROM THE PERSPECTIVE OF THE CRISIS SITUATION}

\begin{abstract}
There are some deciding factors which contribute to forming a demand of comprehensive risk minimalizing means to demand of seeking some potential daily threats in order to their identification and liquidation. These factors are for example: new philosophy of security sciences, desire for keeping the current level of consumption, a dynamization of reality, high awareness or easiness of access to information. It seems that the security culture may support public administration in compliance with social obligations. Moreover, the security culture influence on the crisis management effectiveness and it is conducive to knowledge systematization which is so import and because of the theory which is still modified and week strengthen. Taking into consideration three components of the security culture (resources, an organization and a mentality), it is possible to notice that the efficient counteracting crisis situations would have never happened without a radical intervention into our mentality. From that perspectives the security culture specifies a convention and defines some standards and customs regulating and interpreting security policy of a state. It makes the selection of demanding solutions in crisis management easy.

33 Z innej perspektywy (cywilizacji informacyjnej), ,rozpoznawanie zagrożeń cywilizacyjnych, ich uwarunkowań, zależności, skali ujawniania się oraz skutków, a w tym w kontekście bezpieczeństwa Polski ujawnia konieczność kształtowania kultury bezpieczeństwa na miarę wyzwań teraźniejszości i przyszłości”. Patrz: A. Chodubski, Asymetryczne zagrożenia cywilizacyjne a istota bezpieczeństwa państwa polskiego, w: Zagrożenia asymetryczne współczesnego świata, red. S. Wojciechowski, R. Fiedler, Poznań 2009, s. 48.
\end{abstract}

